\title{
Marine microalgae as a potential source of single cell protein (SCP)
}

Jaime Fabregas, Concepcion Herrero

Departamento de Microbiologia, Facultades de Farmacia y Medicina, Universidad de Santiago de Compostela, Spain

\section{Applied Microbiology and Biotechnology}

December 1985, Volume 23, Issue 2, pp 110-113

DOI 10.1007/BF01982726

\section{Summary}

The marine microalgae Tetraselmis suecica, Isochrysis galbana, Dunaliella tertiolecta and Chlorella stigmatophora are good biological sources of single cell protein (SCP). Protein content accounts for $39.12 \%-54.20 \%$ of the dry matter, $D$. tertiolecta having the highest. Lysine values are between 3.67 and $4.52 \mathrm{~g} / 100 \mathrm{~g}$ of protein, and thus are higher than those for freshwater species. The total nucleic acid content is less than $7 \%$ of the dry matter; this value is definitely lower than that for yeasts or bacteria, commonly used as SCP sources. Amino acid profiles of the four species are very similar and comparable to the FAO reference protein, buth with a low content of methionine and cystine and a high content of lysine. The MEAA indices are between 81 and 84.98, without significant differences among the four species. Marine microalgae can be used as a potential SCP source.

\section{Introduction}

To date, biomass production of microalgae has focused largely on a few freshwater species that were believed to be potential dietary supplements (Becker and Venkataraman 1983; Ciferri 1983). We suggest that marine micro algae can be used as a potential single cell protein (SCP) source. 
We report herein the composition and amino acid pattern of four marine microalgae with respect to their presumptive nutritional assessment.

\section{Materials and methods}

Microorganisms. Four different marine photosynthetic microalgae

were used. Tetraselmis suecica (Prasinophyceae) was isolated from Ria de Arosa waters (N.W. Spain) (Fabregas et al. 1984). Isochrysis galbana (Haptophyceae), Dunaliella tertiolecta and Chlorella stigmatophora (Chlorophyceae) were obtained from The Culture Centre of Algae and Protozoa, Cambridge, England.

Growth. The microorganisms were cultured in seawater filtered through a $0.45 \mu \mathrm{m}$ Millipore filter, autoclaved at $120^{\circ} \mathrm{C}$ for $20 \mathrm{~min}$ and enriched with $\mathrm{NaNO}_{3}, 2 \mathrm{mM}$; $\mathrm{NaH}_{2} \mathrm{PO}_{4}, 100 \mu \mathrm{M} ; \mathrm{ZnCl}_{2}, 1 \mu \mathrm{M} ; \mathrm{MnCl}_{2}, 1 \mu \mathrm{M} ; \mathrm{Na}_{2} \mathrm{MoO}_{4}, 1 \mu \mathrm{M} ; \mathrm{CoCl}_{3}, 0.1 \mu \mathrm{M} ; \mathrm{CuSO}_{4}$, $0.1 \mu \mathrm{M}$; ferric citrate, $20 \mu \mathrm{M}$; thiamine, $35 \mu \mathrm{g} / \mathrm{l}$; biotin, $\mathrm{S} \mu \mathrm{g} / \mathrm{l}$; $\mathrm{B}_{12}, 3 \mu \mathrm{g} / \mathrm{l}$; EDTA, 26.4 $\mu \mathrm{M}$; Tris-HCl, 5 mM; pH, 7.6; salinity, 35\%。 (Fabregas et al. 1984).

Cultures were carried out in 10-I flasks containing 9 I of culture medium. All the cultures were maintained in a controlled environmental incubator at $15 \pm 1{ }^{\circ} \mathrm{C}$ and illuminated with 11 fluorescent lamps (Osram day-light L55/10), 6 under the culture vessels and 5 beside them, giving 6500 and 5500 lux, respectively. A 12: 12 light-dark period was maintained. Cultures were continuously pumped with air at a rate of $15 \mathrm{l} / \mathrm{min}$.

Harvesting and drying. The cells were collected for centrifugation at the end of the logarithmic phase and dryed in an oven at $60^{\circ} \mathrm{C}$ for $24-30 \mathrm{~h}$.

Analysis. The standard AOAC (1980) procedure was used for protein analysis. Crude protein was defined as total nitrogen by 6.25. Ribonucleic acid (RNA) and deoxyribonucleic acid (DNA) were measured as described by Kochert (1978).

Amino acid analysis. The samples were hydrolyzed with $6 \mathrm{~N} \mathrm{HCl}$ at $110^{\circ} \mathrm{C}$ for $24 \mathrm{~h}$. The analysis was performed in a KONTRON automatic amino acid analyser.

Available lysine. Available lysine was calculated by the technique of Carpenter (1960).

Modified essential amino acid (MEAA) index. The MEAA index was determined by the procedure of Oser (1951), as modified by Mitchell (1954), except that tryptophan 
concentrations were not determined and were not included in the calculation of MEAA indexes.

\section{Results and discussion}

The protein content of the marine microalgae assayed accounted for between $39.13 \%$ and $54.20 \%$ of the dry matter. Dunaliella tertiol cta had the highest protein content (Table 1). In comparison, values between $10 \%$ and $46 \%$ (Boyd 1973) or close to $60 \%$ (Aaronson and Dubillsky 1982) of the dry weight have been reported for freshwater microalgal species, including strains considered as possible sources of alimentary protein. Protein levels of our marine micro algae are comparable with these values.

Considering the diversity of size and taxonomic groups involved, the composition of these marine species appears to be remarkably similar and shows, in contrast to terrestrial plants, a general predominance of protein over other constituents.

Available lysine values are between 3.67 and $4.52 \mathrm{~g} / 100 \mathrm{~g}$ of protein (Table 1), whereas Spirulina contains $2.96 \mathrm{~g} / 100 \mathrm{~g}$ of protein and Scenedesmus $3.66 \mathrm{~g} / 100 \mathrm{~g}$ of protein; these are two freshwater micro algae generally used as SCP (Becker and Venkataraman 1982). It has been observed that there is a good correlation between the biological value of foodstuffs and the level of available lysjne in the protein content (Carpenter 1960). The biological value of these marine microalgae can thus be considered as good with respect to their lysine content.

Table 1. Chemical composition of different marine microalgae. Protein and nucleic acids are expressed as \% of dry matter and available lysine as $\mathrm{g} / 100 \mathrm{~g}$ of protein

\begin{tabular}{lllrr}
\hline & $\begin{array}{l}\text { Tetraselmis } \\
\text { suecica }\end{array}$ & $\begin{array}{l}\text { Isochrysis } \\
\text { galbana }\end{array}$ & $\begin{array}{l}\text { Dunaliella } \\
\text { tertiolecta }\end{array}$ & $\begin{array}{l}\text { Chlorella } \\
\text { stigmatophora }\end{array}$ \\
\hline Crude protein & 41.39 & 39.23 & 54.25 & 39.13 \\
Available lysine & 4.45 & 3.67 & 4.52 & 3.71 \\
RNA & 4.83 & 4.36 & 6.18 & 0.65 \\
DNA & 0.60 & 0.70 & 4.83 & 6.56 \\
Total nucleic acids & 5.43 & 5.06 & 6.72
\end{tabular}

In these marine micro algae the RNA represents $4.18 \%-6.16 \%$ of the dry weight, whereas the DNA represents only $0.56 \%-0.70 \%$ (Table 1 ). Because uric acid is produced in humans and other mammals in the metabolism of purines and high levels of this metabolite may cause pathological conditions such as gout, a constant worry in the utilization of microbial cells as food or feed has been their high nucleic acid content (Ciferri 1983). In marine microalgae RNA has been reported to represent 0.7\%-6.65\% of the dry weight and DNA $0.31 \%-0.86 \%$ (Parsons and Takahashi 1973). Our results 
are in agreement with these data. The total nucleic acid content, therefore, is less than $7 \%$ of the dry weight, a value close to that reported for freshwater unicellular algae, but definitely less than that of yeast (8\%-12\%) or bacteria (9\%-22\%) (Ciferri 1983).

There are no substantial differences in the amino acid composition of the protein from the four marine micro algae assayed (Table 2). In Table 2 the amino acid compositions of the marine microalgae are compared with that of the reference protein of the Food and Agricultural Organization (FAO 1970), with some other single cell protein from freshwater micro algae (Becker and Venkataraman 1982) and with conventional foods (Documenta Geigy 1975; Gordon and Whittier 1966).

The amino acid patterns are comparable with that of the FAO reference protein, except for the low contents of methionine and cystine, which are also very common in other microorganisms (Riviere 1977). Most single cell proteins produced to date are deficient in methionine (Kilhberg 1972) and cystine (Ciferri 1983). Proteins from marine micro algae examined in this study were also low in methionine and cystine, compared with the quantity in the FAO reference protein. Methionine is somewhat labile to acid hydrolysis (Menden and Cremer 1970). The values reported in Table 2 for methionine thus underestimate the actual methionine concentration in the protein of the microalgae.

Table 2. Amino acid profiles and MEAA index of protein from marine microalgae, FAO reference protein and certain protein from freshwater microalgae and conventional foods. Amino acid concentrations are expressed as grams of amino acid per $16 \mathrm{~g}$ of $\mathbf{N}$

ILE LEU LYS MET PHE THR VAL TYR ALA ARG ASP CYS GLU GLY HIS PRO SER MEAA

index

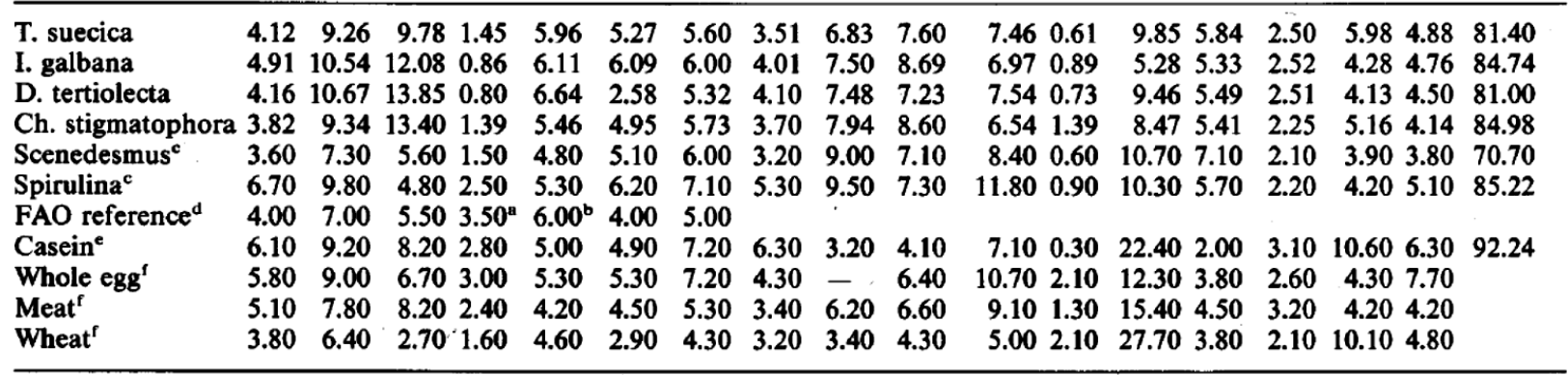

a Value reported is the sum of values for methionine + cystine

b Value reported is the sum of values for phenylalanine + tyrosine

c Becker and Venkataraman 1982

d FAO 1970

e Gordon and Whittier 1966

f Documenta Geigy 1975 
In contrast to other freshwater micro algae commonly used as protein sources (Becker and Venkataraman 1982; Ciferri 1983), proteins from the four marine microalgae were found to be rich in lysine. Lysine is the most limiting essential amino acid in cereals, but it is present in higher concentrations in animal protein from sources such as beef and eggs. The lysine concentration in marine micro algae species surpassed that in beef or whole egg (Table 2).

The remaining amino acids present a well-balanced distribution. Because tryptophan is destroyed during acid hydrolysis this amino acid is not reported.

The amino acid concentrations in a protein source may have no relationship to the biological availability of these amino acids (PAG 1974). To make a preliminary assessment of the nutritional value of the protein from these marine microalgae, the MEAA index was determined for each microalgal type (Table 2). The MEAA index is a measure of the levels of all the essential amino acids in the test protein versus those in the whole egg protein (PAG 1974). No significant differences in MEAA indices for the protein from the four marine microalgae were observed (values between 81 and 84.98). Comparing these indices with those of casein (92.24) and other freshwater micro algae (70.72 for Scenedesmus and 85.22 for Spirulina) significant differences were not observed either.

In view of the results obtained in this study we conclude that the biological value of the marine microalgae can be considered as good and these microalgae can be used as a potential SCP.

\section{Acknowledgements.}

This work was supported by a grant of Dirección General de Ordenación Pesquera, Madrid, Spain.

Thanks are due to Prof. Dr. B. Regueiro Varela for his interesting comments and to Jose R. Alonso and Jose L. Barreiro, Hospital General de Galicia, for excellent technical help in conducting amino acid analysis. Part of this work was supported by a grant to C. H. from Fundación Juan March, Madrid, Spain. 


\section{References}

1. Aaronson S, Dubinsky Z (1982) Mass production of microalgae. Experientia 38:36-40

2. A.O.A.C. (1980) Official methods of analysis, 13th edn. Association of Official Agricultural Chemist, Washington, DC

3. Becker EW, Venkataraman LV (1982) Biotechnology and exploitation of algae - the Indian approach. Agency for Technical Cooperation (GTZ) D-6236 Eschlorm, Federal Republic of Germany

4. Boyd CE (1973) Amino acid composition of freshwater algae. Arch Hydrobiol 72:1-9

5. Carpenter KJ (1960) The estimation of available lysine in animal-protein foods. Biochem J 77 (3):604-610

6. Ciferri O (1983) Spirulina, the edible microorganism. Microbiol Rev 47 (4):551-578

7. Documenta Geigy (1975) J. R. Geigy, Basle, Switzerland

8. Fabregas J, Herrero C, Cabezas B, Abalde J, Veiga M (1984) Growth of the marine microalga Tetraselmis suecica in batch cultures with different salinities and nutrient concentrations. Aquaculture 42:207-215

9. Food and Agriculture Organization of the United Nations (1970) Amino acid content of foods and biological data on proteins. FAO nutritional studies, no. 24. Rome, Italy

10. Gordon WG, Whitier EO (1966). In: Webb BH, Johnson AH (Eds) Fundamentals of dairy chemistry. Avi Publishing Co., Westport, Conn., USA

11. Kihlberg R (1972) The microbe as source of food. Ann Rev Microbiol 26:427-466

12. Kochert G (1978) Quantitation of the macromolecular components of microalgae. In: Hellebust JA, Craigie SS (eds) Handbook of phycological methods. Physiological and biochemical methods. Cambridge University Press, pp 189-195

13. Menden E, Cremer HD (1970) Laboratory methods for the evaluation of changes in protein quality. In: Alnanese AA (ed) Newer methods of nutritional biochemistry with applications and interpretations. Academic Press, New York, pp 123-161

14. Mitchell HH (1954) Biological values of proteins and amino acids interrelationships. In: Spector H, Peterson MS, Friedman TE (eds) Symposium on methods for the evaluation of nutritional adequacy and status. National Research Council, Washington, DC, pp 13-28

15. Oser BL (1951) Method for integrating essential amino acid content in the nutritional evaluation of protein. J Am Diet Assoc 27:396-402

16. Parsons TR, Takahashi M (1973) Biological oceanographic processes. Pergamon Press, Oxford, pp 39-49

17. Protein-Calory Advisory Group of the United Nations System (1974) Fourth meeting of the PAG ad hoc working group on single cell protein. PAG Bull 4:9-31

18. Riviere J (1977) Microbial proteins. In: Moss MO, Smith JE (eds) Industrial applications of microbiology. Surrey University Press, pp 105-149 